\title{
ASEAN NCAP-The Best Bet for Vehicle Safety in the Region's Safe System?
}

\author{
Zulhaidi Mohd Jawi, Khairil Anwar Abu Kassim, and Ahmad Farhan Sadullah
}

\begin{abstract}
This paper discusses the activity carried out in the ASEAN region to elevate road safety situation, which has been inspired by the United Nations' Decade of Action for Road Safety 2011-2020. The newly established New Car Assessment Program for Southeast Asian Countries (ASEAN NCAP) is expected to contribute in lowering the accident risk and also the extremity of casualties from motor vehicle accidents by introducing the automobile safety rating, which has long been established in other developed countries. This regional effort is set to create a new paradigm shift in the ASEAN's automotive ecosystem with its two-pronged approach by bringing up the level of automotive consumerism as well as promoting the up-to-date safety technologies in passenger vehicles by the industries.
\end{abstract}

Index Terms-ASEAN, new car assessment program, safe system, UN decade of action for road safety 2011-2020.

\section{INTRODUCTION}

The establishment of the New Car Assessment Program for Southeast Asian Countries, or known as ASEAN NCAP, in 2011 has brought several notable meanings to the region's socioeconomic development, particularly road safety. This effort repeats the history of Malaysia's contribution to the Southeast Asia region development e.g. for the move to initiate the Zone of Peace, Freedom and Neutrality (ZOPFAN) that was eventually becoming one of the policies adopted by the Association of Southeast Asian Nations (ASEAN) [1]. While ZOPFAN is taking care of sustainable peace and stability for the region, ASEAN NCAP is contributing to the modern day's sustainability in transportation.

The ASEAN communities are experiencing growth at variable rate despite the fact that the ASEAN region as a whole is categorized as one of the world's emerging economies [2]. This fact has explained the socioeconomic disparities in the region, which can also be seen in the transportation sector. Motorcycles dominate the region's motorized vehicle population which can be safely estimated to be more than half of the total registered vehicles [3]. On the other hand, the passenger cars sector is experiencing considerable growth as the demand rises significantly for the comfort of four-wheeler private vehicles e.g. cars,

Manuscript received June 22, 2013; revised August 23, 2013. This work is funded primarily by Malaysian Institute of Road Safety Research (MIROS) and Global New Car Assessment Programme (Global NCAP).

Zulhaidi Mohd Jawi and Khairil Anwar Abu Kassim are with the Malaysian Institute of Road Safety Research (MIROS), Kajang, 43000 Malaysia (e-mail: zulhaidi@ miros.gov.my, khairilanwar@ miros.gov.my).

A. F. Sadullah is with the Universiti Sains Malaysia (USM), Georgetown, 11800 Malaysia (e-mail: cefrhn@eng.usm.my).
Multi-purpose Vehicles (MPVs) and Sport Utility Vehicles (SUVs); from here will be referred to as "cars". Frost \& Sullivan has estimated that ASEAN's vehicle sales will double in 2018 as compared to 2.4 million in 2011 and consequently becomes the world's sixth biggest automotive market [4]. This will also increase the region's average car density, which currently standing at 44 cars per one thousand inhabitants [5]. Therefore, what worries the road safety stakeholders the most is the side effect of this socioeconomic expansion which may result in more severe road crashes outcomes due to road sharing conflicts between two- and four-wheeled vehicles as well as crash compatibility issue. On top of that, developing ASEAN countries will face the more risks and outcomes from increased in exposures due to greater vehicle kilometers travelled (VKT), and more high-speed environment i.e. more highways are built.

\section{SAFER Vehicles Via The United NATIONS' DeCADE OF ACTION FOR ROAD SAFETY 2011-2020}

The Commission for Global Road Safety issued for a Decade of Action Document for Road Safety [6], in 2009, which is comprised of three main components as follows:

1) Goals and specific objectives, with an agreed target.

2) Activities designed to achieve the specific target through a series of indicators.

3) Funding commensurate to the activities.

Within the Decade of Action's epoch between the years 2011 until 2020, the scenario to be achieved is that the increasing trend in road traffic fatalities around the world to be halted and to be reversed together with an increasing activities at the national level to achieve the target. While coordination and global architecture for road safety will be strengthened at the international level, more focused endeavors (pillars) are set at the regional or national level as illustrated in Fig. 1.

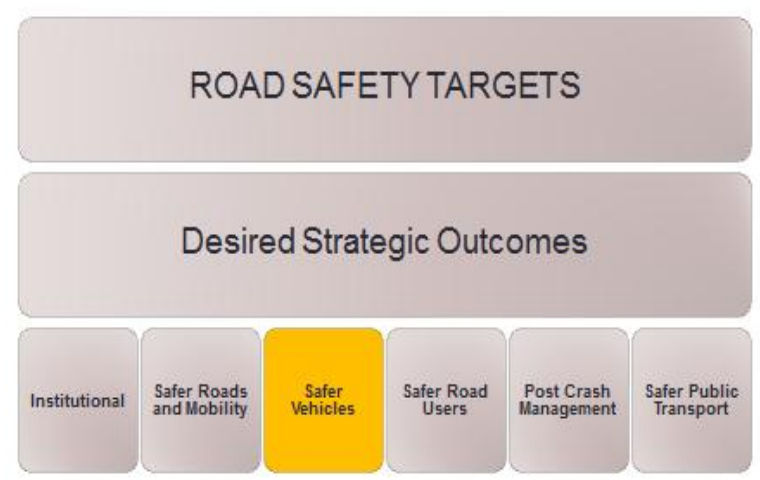

Fig. 1. Pillars contributing to desired strategic outcomes in achieving road safety targets. 
Safer vehicles pillar revolves around the global deployment of vehicle safety technologies for both passive and active safety through a combination of harmonized relevant global standards, and consumer information schemes and incentives to accelerate the uptake of new technologies [6]. Decade of Action has outlined several specific activities to achieve the target, in which ASEAN NCAP is the manifestation of Activity No. 2 in safer vehicles pillar i.e. implementation of new car assessment programs in all world regions to increase the availability of consumer information about the safety performance of motor vehicles.

\section{ASEAN NCAP - HISTORICAL BACKGROUND AND ASSESSMENT METHODOLOGIES}

Prior to the Decade of Action declaration, Malaysia has set its own initiative to enhance road safety situation in the country through the Road Safety Plan of Malaysia 2006-2010 [7]. The plan consists of many strategic areas that has been mapped on a "Haddon Matrix" format, and had insisted the establishment of a research and development agency known as the Malaysian Institute of Road Safety Research (MIROS). Therefore, MIROS has adopted the plan to become "MIROS Integrated Planning Matrix," which has also served as its key performance indicators [8]. One of the items under the traffic system component of "Vehicle" and temporal sequence of "Pre-Crash" is to establish an NCAP rating program in the country (Table I).

TABLE I: NCAP AS A PROGRAM IN HADDON MATRIX

\begin{tabular}{|c|c|c|c|}
\hline $\begin{array}{c}\text { Temporal } \\
\text { Sequence/ } \\
\text { Components }\end{array}$ & $\begin{array}{c}\text { Pre- } \\
\text { Crash }\end{array}$ & In Crash & $\begin{array}{c}\text { Post- } \\
\text { Crash }\end{array}$ \\
\hline Human & Factor & Factor & Factor \\
\hline Vehicle & NCAP & Factor & Factor \\
\hline Road & Factor & Factor & Factor \\
\hline
\end{tabular}

The first move to achieve this ambitious target was the creation of a rating program called Malaysian Vehicle Assessment Program (MyVAP) whereby the assessment is primarily based on secondary data provided voluntarily by the Original Equipment Manufacturers (OEMs) [9]. MyVAP functions as the catalyst to the introduction of Malaysia NCAP (MyNCAP) by cultivating the culture of vehicle star-rating assessment. Meanwhile, in the period between 2008 until 2011, MIROS had also established its own capacity to conduct crash testing through many series of facilities benchmarking, staff training, outdoor crash tests and also strategic collaborations with related international bodies.

Global NCAP, which its establishment was also inspired by the Decade of Action has come at the right time and turned the original idea of MyNCAP to somewhat greater initiative which today known as ASEAN NCAP. A Memorandum of Understanding that was signed-off during the FIA Annual General Assembly in New Delhi, India in December 2011 marked the official commitment by MIROS and Global NCAP towards realizing the ASEAN NCAP idea [10]. This movement is also supported by the membership of automobile associations from Malaysia (AAM), the Philippines (AAP) and Singapore (AA Singapore). At the same time, MIROS was about ready to operate its very own crash lab, known as MIROS PC3. Therefore, the launch of ASEAN NCAP test in November 2012 had confirmed the existence of such program in the region and the latest among all NCAP programs globally [11]. ASEAN NCAP is the fourth NCAP in Asia continent after Japan, South Korea, and China. Table II lists all NCAP programs in the world, which can be categorically divided into country-based or regional-based program.

TABLE II: NCAP PROGRAMS IN THE WORLD

\begin{tabular}{|c|c|c|c|}
\hline \multirow{4}{*}{ Continent } & Country/Region & Program Name & $\begin{array}{c}\text { Year } \\
\text { Established }\end{array}$ \\
\cline { 2 - 4 } & China & C-NCAP & 2006 \\
\cline { 2 - 4 } & Japan & J-NCAP & 1991 \\
\cline { 2 - 4 } Australia & $\begin{array}{c}\text { Australia \& New } \\
\text { Zealand }\end{array}$ & K-NCAP & 1999 \\
\hline \multirow{3}{*}{ Europe } & $\begin{array}{c}\text { France, } \\
\text { Germany, Italy, } \\
\text { Spain, Sweden, } \\
\text { The Netherlands } \\
\& \text { UK }\end{array}$ & Euro-NCAP & 2011 \\
\hline \multirow{2}{*}{$\begin{array}{c}\text { North } \\
\text { America }\end{array}$} & $\begin{array}{c}\text { USA } \\
(\text { Insurance) }\end{array}$ & $\begin{array}{c}\text { IIHS } \\
\text { Ratings }\end{array}$ & 1992 \\
\cline { 2 - 4 } & $\begin{array}{c}\text { USA } \\
(\text { NHTSA }\end{array}$ & US NCAP & 1959 \\
\hline $\begin{array}{c}\text { South } \\
\text { America }\end{array}$ & $\begin{array}{c}\text { Latin America \& } \\
\text { Caribbean }\end{array}$ & Latin NCAP & 2010 \\
\hline
\end{tabular}

${ }^{\mathrm{a}}$ Insurance Institute for Highway Safety

${ }^{\mathrm{b}}$ National Highway Traffic Safety Administration

Similar to Latin NCAP, ASEAN NCAP by far only performs one crash test - frontal offset test - that produces two separate ratings - Adult Occupant Protection (AOP) and Child Occupant Protection (COP) [12]. Other NCAPs are basically producing a single rating system that is sourced from weighted scores from many tests e.g. full-wrap frontal test, side impact test, pedestrian protection test, and active safety/safety assist equipment fitment and/or its performance.

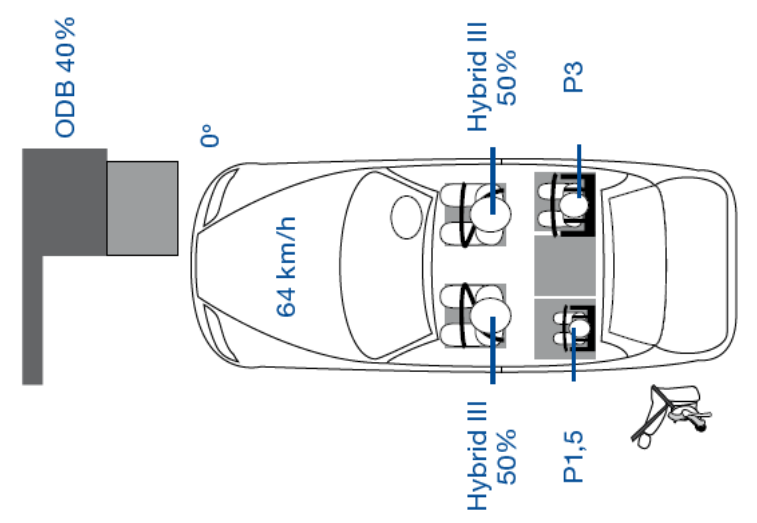

Fig. 2. ASEAN NCAP frontal offset test.

Fig. 2 illustrates the ASEAN NCAP frontal $40 \%$ offset test that consists of two Hybrid III dummies $\left(50^{\text {th }}\right.$ percentile male) and two child dummies (P3 for 3 year-old; P1.5 for 18 month-old) inside the Child Restraint System (CRS). The car is propelled until it hits a crushable aluminum barrier (Offset Deformable Barrier - ODB) at the closing speed of $64 \mathrm{~km} / \mathrm{h}$. The dummies' sensors will provide readings according to the body region, and basically the worst results from each body 
region (head; neck; chest; femurs; knees; upper \& lower legs) - compared between the driver and front passenger - are considered and accumulated in AOP assessment. However, the score is subjected to post-test assessment known as "modifier" that could reduce the score (penalty) to produce the final AOP score. Similarly, COP will also be based on in-dummy sensors readings i.e. dynamic test score, however, the final score will also be influenced by CRS-based assessment and vehicle-based assessment to reward the compatibility, ease-of-use and safety factors in using CRS (Table III). Car users can simply refer to both AOP and COP ratings, in which the former is marked by 5-star as the best and the latter with $\mathbf{1 0 0 \%}$ as the best (Fig. 3).

TABLE III: SCORING SCHEME FOR AOP \& COP

\begin{tabular}{|c|c|c|c|}
\hline \multicolumn{2}{|c|}{ Adult Occupant Protection } & \multicolumn{2}{|c|}{ Child Occupant Protection } \\
\hline Final Score & Star Rating & Dynamic Test & $24 / 24$ \\
\hline $14.00-16.00$ & 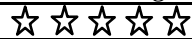 & \multirow{2}{*}{$\begin{array}{l}\text { CRS Based } \\
\text { Assessment }\end{array}$} & \multirow{2}{*}{$12 / 12$} \\
\hline $11.00-13.99$ & 它公公公 & & \\
\hline $8.00-10.99$ & 象余余 & \multirow{2}{*}{$\begin{array}{c}\text { Vehicle Based } \\
\text { Assessment } \\
\end{array}$} & \multirow{2}{*}{$13 / 13$} \\
\hline $5.00-7.99$ & 公允 & & \\
\hline $2.00-4.99$ & 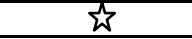 & TOTAL & $49 / 49$ \\
\hline $0.00-1.99$ & Zero-Star & Compliance (\%) & $100 \%$ \\
\hline
\end{tabular}

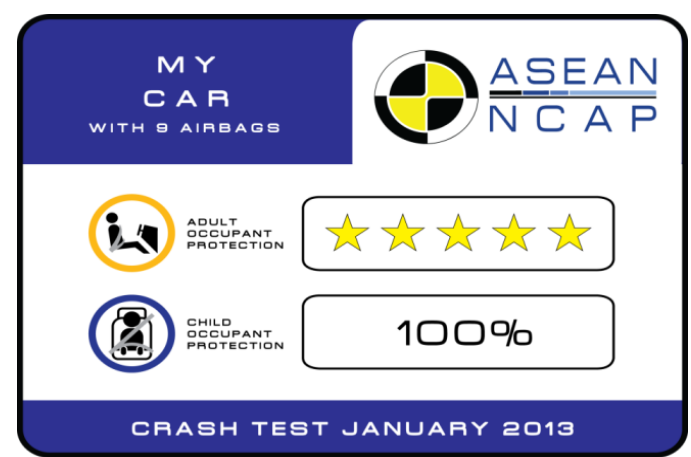

Fig. 3. ASEAN NCAP rating plate.

At this initial stage, ASEAN NCAP also introduces the active safety elements in the assessment scoring in the form of pre-requisite. As crash test is by and large the manifestation of passive safety to measure the ability of a car to protect its occupants in the event of road crashes, active safety or safety assist technologies (SATs) is referring to pre-crash crash avoidance or risk of crash/injury mitigation effort. Therefore, ASEAN NCAP requires the standard fitment of advanced braking technology known as Electronic Stability Control (ESC) and Seatbelt Reminder (SBR) to ensure AOP 5-star eligibility. This will basically affect cars that have scored 5-star range for AOP but have to be relegated to 4-star due to the absence of either ESC or SBR.

\section{NCAP CONTRIBUTION IN THE AUTOMOTIVE ECOSYSTEM - SYSTEMS THINKING POINT OF VIEW}

NCAP effort would be best represented in a "big picture" road safety solution framework; in vehicle safety per se. Haddon Matrix, which has inspired MIROS Integrated Planning Matrix, was originally the first attempt to define traffic safety systems in a "big picture" perspective by Dr. William Haddon in 1970 [13]. The traffic safety variables were divided into temporal sequence and traffic system components and arranged into rows and columns (nine cells) in which interventions could be initiated to prevent road accidents as illustrated in Table I. As mentioned previously, MIROS has adopted this matrix into its planning, in which the NCAP as a program serving as a pre-crash intervention under the traffic system component of "Vehicle" and temporal sequence of "Pre-Crash." However, the details in NCAP assessment are actually targeting on other cells in the matrix e.g. airbags and restraint systems (passive safety) are contributing to mitigate injuries at the moment of impact (within about 40 milliseconds); active safety items such as ESC and SBR (active safety) are actually dealing with human factors (weaknesses) by virtue of advance technologies in the form of correcting and/or giving warning (Table IV).

TABLE IV: NCAP ASSESSMENT ELEMENTS

\begin{tabular}{|c|c|c|c|}
\hline $\begin{array}{c}\text { Temporal } \\
\text { Sequence/ } \\
\text { Components }\end{array}$ & $\begin{array}{c}\text { Pre- } \\
\text { Crash }\end{array}$ & In Crash & $\begin{array}{c}\text { Post- } \\
\text { Crash }\end{array}$ \\
\hline Human & Active Safety & $\begin{array}{c}\text { Active/Passive } \\
\text { Safety }\end{array}$ & Passive Safety \\
\hline Vehicle & Active Safety & Passive Safety & Passive Safety \\
\hline Road & Active Safety & Factor & Factor \\
\hline
\end{tabular}

Other than Haddon Matrix, road safety researchers had also introduced many other systems thinking on road safety outlook such as the three E's (engineering, enforcement and education), the four E's with the addition of environment factor, as well as the more comprehensive outlook such as "C3-R3 Traffic Safety Systems Approach" as in Fig. 4 [13].

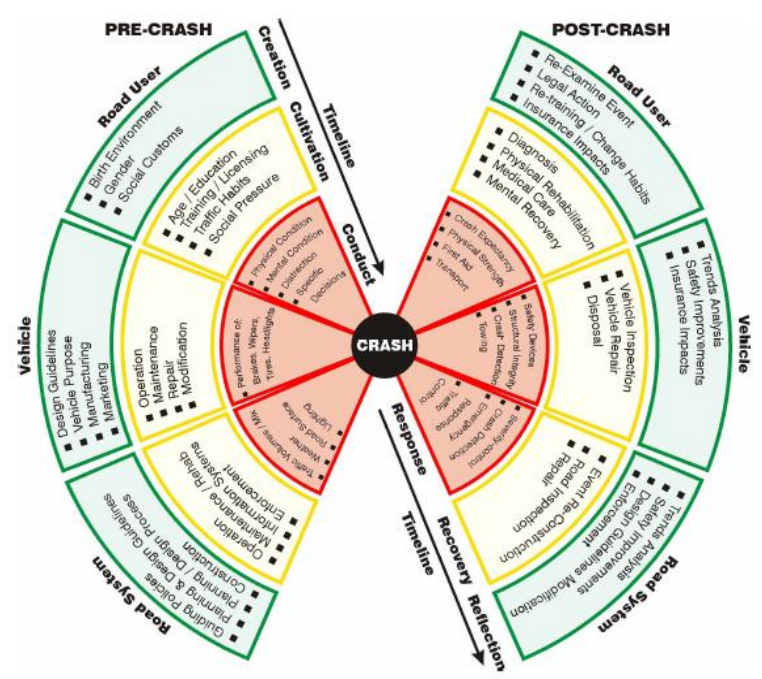

Fig. 4. C3-R3 traffic safety systems approach.

The "vehicle creation" phase in the C3-R3 systems approach has outlined the motivation that "vehicles are created to meet safety and operational criteria, and are designed to meet market demands" [13]. In reality, safety standards and market demand would vary between countries or regions due to unique vehicle legislation framework as well as the consumers' awareness towards vehicle safety. Job et al. in 1989 had come out with the following note: "many fatalities occur not because of driver error but because of driver error combined with a negligent designed road system and a politically acceptable but technically substandard vehicle. Most of us would not condone a legal system which 
handed out the death penalty (or permanent disability) for "crimes" such as the misjudging of the camber of the road or driving when slightly drowsy, so we should not accept a politically determined traffic system which metes out such penalties" [14]. Therefore, how will ASEAN NCAP make a difference in the region's safe system with regard to vehicle safety?

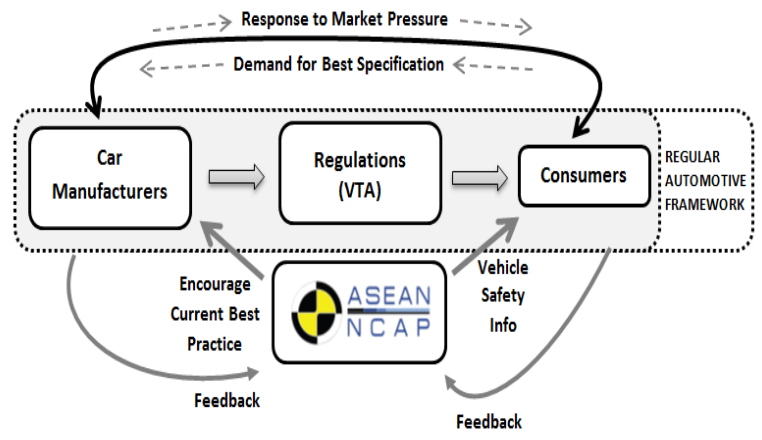

Fig. 5. Role of ASEAN NCAP in promoting safer vehicle environment.

The NCAP program acts as the third party between car manufacturers (OEMs) and consumers. This claim is not to undermine other third parties which play the same role such as the consumer associations. In fact, consumer associations are the key players behind the NCAP program due to the comprehensive nature in the NCAP assessment.

Fig. 5 illustrates the role of NCAP in promoting safer vehicle environment in the regular automotive framework where the consumers are solely dependent on domestic vehicle regulations, including the Vehicle Type Approval (VTA) exercise. The dissemination of vehicle safety info and also the ratings will increase consumers' awareness and therefore they become more demanding on safety.

Ideally, the OEMs will react to the market pressure and also the encouragement for best practice outlined in NCAP protocols. Fig. 6 is an alternative picture of NCAP function, based on the reinforcing loop in a systems map [15].

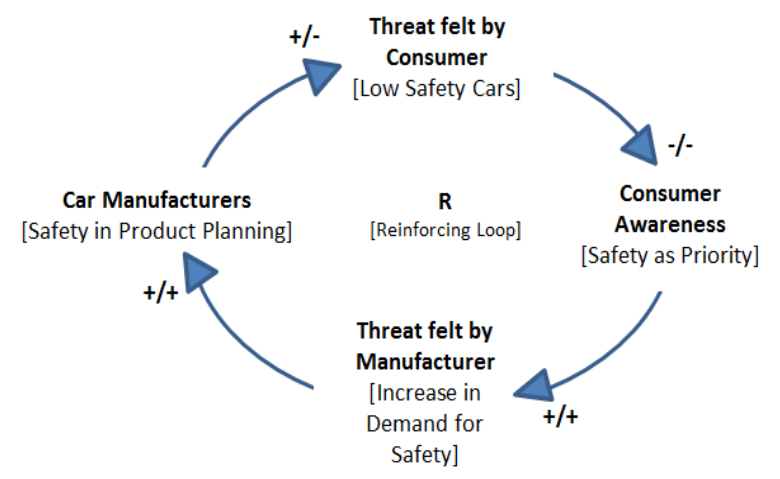

Fig. 6. NCAP in a reinforcing loop in systems map.

TABLE V: MAIN FACTORS IN CAR BUYING DECISION

\begin{tabular}{|c|c|c|c|}
\hline \multirow{2}{*}{ Country } & \multicolumn{3}{|c|}{ Top 3 Factors } \\
\cline { 2 - 4 } Malaysia & 1st & 2nd & 3rd \\
\hline Fafety & Comfort & Price \\
\hline Thailand & Price & Style/Design & $\begin{array}{c}\text { Safety } \\
\text { Features }\end{array}$ \\
\hline Singapore & Price & Comfort & Style/Design \\
\hline The Philippines & Price & Safety Features & Comfort \\
\hline
\end{tabular}

In this systems map, the more awareness shown by the consumers in safety, the more is felt by OEMs in demand for safety. Thus, OEMs will revise safety features in current model as well as embedding considerable safety features in their future models, perhaps with NCAP as the ultimate benchmark. As this goes for several cycles, consumers will feel less threat from OEMs in terms of low safety cars and the consumers are therefore have more liberty to choose from other features of cars e.g. fuel efficiency, interior design, exterior design, etc. A public survey that was conducted by ASEAN NCAP in 2012 in four ASEAN countries shows that safety is not necessary the first thing in consumers' mind when they are buying cars, as described in Table V [16].

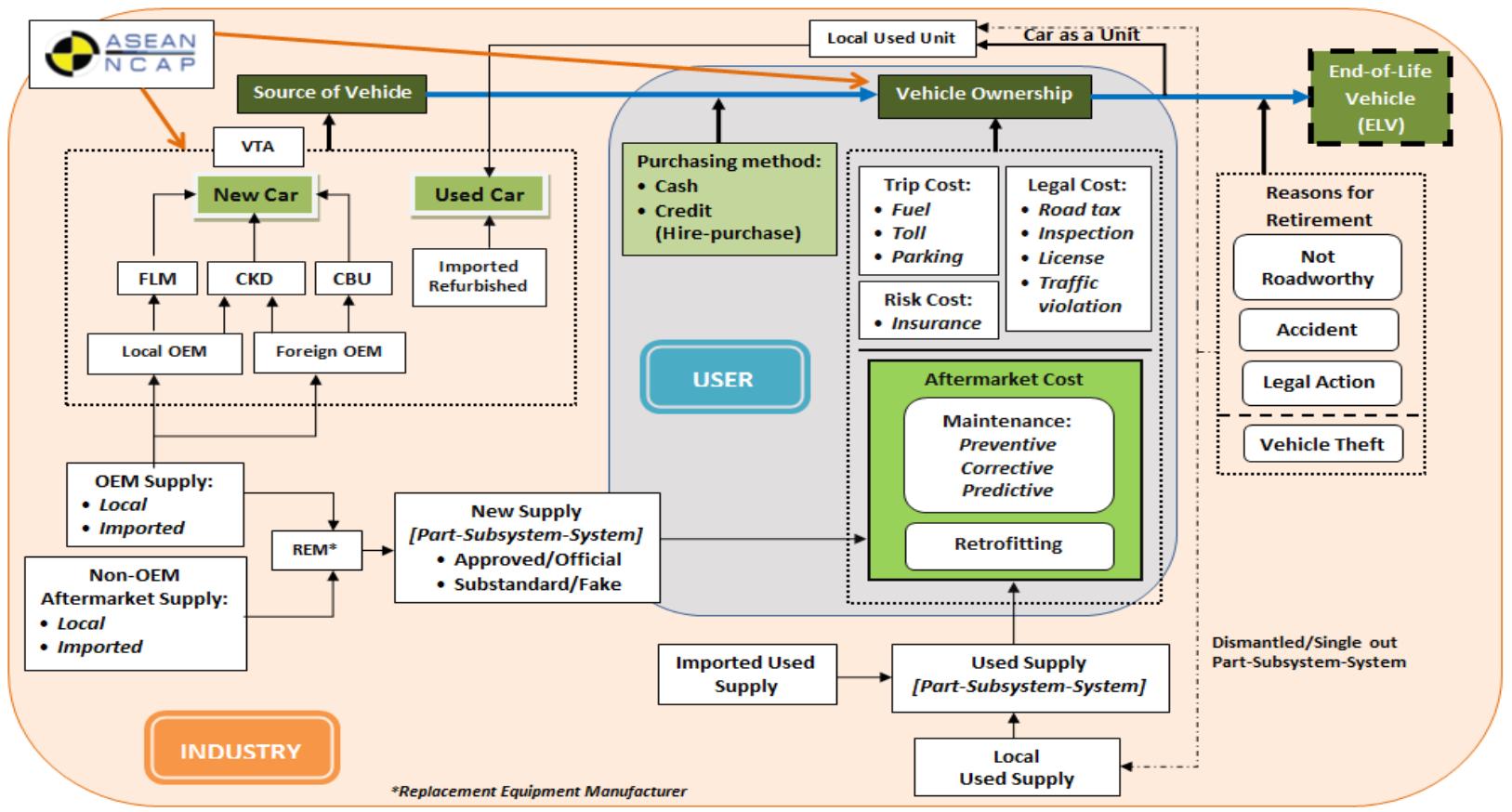

Fig. 7. NCAP in the Malaysia's automotive ecosystem. 
In a bigger perspective, ASEAN NCAP will influence each country unique automotive ecosystem as illustrated for Malaysian case in Fig. 7. It is set to make a paradigm shift in new car sector other than VTA exercise, as well as in the vehicle ownership environment particularly in buying new cars [17].

\section{CONCLUSion AND Future ChaLlenges}

In a nutshell, ASEAN NCAP will play its role in the region's safe system in educating the consumers as well as encouraging the OEMs to provide safer cars. In view of United Nations' Decade of Action for Road Safety, ASEAN NCAP can be regarded as the corrective measures for the region's more developed economies such as Singapore, Malaysia, Thailand, Brunei and the Philippines; and as well being a preventive tool to the rest of the countries in tackling safe car issue in the transportation system.

On another note, sustainability and expansion of the test spectrum will be the main challenges to the program. In fact, both factors are interrelated whereby expanding the assessment scheme will require more resources, monetary and non-monetary combined. As mentioned above, the current scheme only consist of one crash test and require more test such as side impact and pedestrian protection test. The ultimate goal for NCAP is the moment when it can execute an assessment that represent the prevailing road safety issue in the region i.e. motorcycle related issues from the vulnerable road users (VRUs) group. A strong resource is also needed for an effective information dissemination framework to cater successful coverage to the region's wide-range target audience.

\section{ACKNOWLEDGMENT}

The authors would like to express their gratitude to those who helped in preparing this manuscript. Special mention to the Director-General of MIROS, Director of Vehicle Safety \& Biomechanics Research Centre of MIROS, and the great people from MIROS' Crash Safety Engineering Unit (CRASE) as well as MIROS PC3 Crash Laboratory.

\section{REFERENCES}

[1] J. Saravanamuttu. (November 2012). Malaysia in the New Geopolitics of Southeast Asia. The New Geopolitics of Southeast Asia. LSE Ideas. [Online]. http://www.lse.ac.uk/IDEAS/publications/reports/SR015.aspx

[2] APEC, Socio-Economic Disparity in the APEC Region, APEC Economic Committee, Singapore: APEC Secretariat, 2006

[3] WHO, Global Status Report on Road Safety: Time for Action, Geneva: World Health Organization, 2009.

[4] Motor Trader. (August 16, 2012). ASEAN vehicle sales to reach 4.7 million units by $2018 . \quad$ [Online]. Available: http://www.motortrader.com.my/news/asean-vehicle-sales-to-reach-47-million-units-by-2018/

[5] Deutsche Bank Research. (September 29, 2011). ASEAN auto market - Growing in the shadow of China and India. [Online]. Available: http://www.dbresearch.com/PROD/DBR_INTERNET_EN-PROD/PR OD0000000000278738.PDF

[6] A. F. Sadullah, "Vehicle safety: the decade of action best bet?" presented at the Automotive Safety Week 2012: Southeast Asia, Melaka, Malaysia, May 22-25, 2012.

[7] Road Safety Department of Malaysia, Road Safety Plan of Malaysia 2006-2010, Putrajaya: Ministry of Transport Malaysia, 2006.
[8] A. F. Sadullah, "Road safety research programs in Malaysia," in Proc. 2008 Australasian Road Safety Research, Policing and Education Conf., Adelaide, 2008.

[9] A. A. Hafeez, M. J. Zulhaidi, A. Yahaya, S. M. Syazwan, and Y. Fazli, Malaysian Vehicle Assessment Programme: PROTON EXORA - a 4-Star MPV in Safety, MER 09/2009, Kuala Lumpur: Malaysian Institute of Road Safety Research, 2009.

[10] Global NCAP. (December 8, 2012). ASEAN NCAP: Making Cars Safer in ASEAN Region. [Online]. Available: http://www.globalncap.org/News/News_archive/2011/Pages/makingcars-safer.aspx

[11] Global NCAP. (November 16, 2012). ASEAN NCAP Launches Its Phase I Crash Test Programme. [Online]. Available: http://www.globalncap.org/News/News_archive/2012/Pages/ASEAN NCAPlaunchesitsPhaseIcrashtestprogramme.aspx

[12] ASEAN NCAP Phase I Official Result Handbook, ASEAN NCAP Communications, Kuala Lumpur: ASEAN NCAP, January 2013.

[13] S. R. Zein and F. P. D. Navin, "Improving traffic safety: The C3-R3 systems approach,” presented at 2003 Transportation Research Board Annual Meeting, Washington D.C., 2013.

[14] L. Mooren, R. Grzebieta, and S. Job, "Safe system-comparisons of this approach in Australia," presented at 2011 Australasian College of Road Safety National Conference, Melbourne, 2011.

[15] R. Ricigliano and D. Chigas, Systems Thinking in Conflict Assessment-Concept and Application, Washington D.C.: U.S. Agency for International Development (USAID), November 2011

[16] M. I. M. Hafzi, A. A. Hafeez, M. J. Zulhaidi, S. M. Syazwan, R. M. Khairudin, P. N. Faradila, J. M. Hafiz, H. Azhar, A. K. K. Anwar, and S. V. Wong, Public Perception towards Vehicle Safety in the Southeast Asia Region-A Report Submitted to Global NCAP, Kuala Lumpur: ASEAN NCAP, July 2012.

[17] M. J. Zulhaidi, L. Fauziana, A. M. A. Rahmat, A. K. K. Anwar, A. Fuad, and S. V. Wong, Review of the National Automotive Policy on Car Maintenance Issues: Malaysia's Automotive Ecosystem Explained, MRev. 02/2012, Kuala Lumpur: Malaysian Institute of Road Safety Research, 2012.

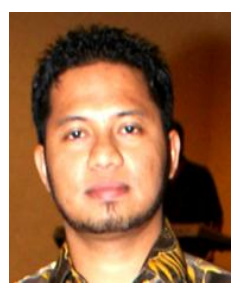

M. J. Zulhaidi is a member of Society of Automotive Engineers (SAE) - Malaysia Section. He is graduated in Systems \& Control Engineering from Case Western Reserve University, Cleveland, Ohio, USA in 2006 He currently holds the position of research officer at the Malaysian Institute of Road Safety Research (MIROS) in Kajang, Malaysia. His research interest is ranging from technical to educational field focusing on road safety research and development i.e. systems thinking in automotive ecosystem, roadworthiness and crashworthiness study, real-world crash investigation, driver's education and curriculum, and weather-related road accident study. Mr. Zulhaidi is also a member of the Malaysia Board of Engineers (BEM) and Transportation Science Society of Malaysia (TSSM). He is also the acting communications manager for ASEAN NCAP.

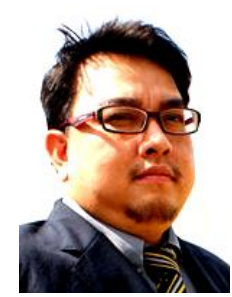

A. K. Khairil Anwar is the vice chairman of Society of Automotive Engineers (SAE) - Malaysia Section. $\mathrm{He}$ is graduated in Mechanical Engineering from Okayama University of Science, Okayama Prefecture, Japan in 2000. He also obtained a master's degree in Engineering Management from Universiti Putra Malaysia (UPM) in 2008. He currently holds the position of NCAP development manager at the Malaysian Institute of Road Safety Research (MIROS) in Kajang, Malaysia. His expertise is automotive safety as well as project management. Prior to MIROS, he used to work with world-renowned automotive safety company Autoliv for several years. He is the inaugural head of Unit of MIROS' Crash Safety Engineering (CRASE) that is responsible for the development of MIROS crash test capability, including the development of MIROS PC3 crash laboratory in Melaka, Malaysia. Mr. Khairil Anwar is also a member of the Malaysia Board of Engineers (BEM), and holds the position of ASEAN NCAP Secretary-General and Chairman of the Technical Committee. 


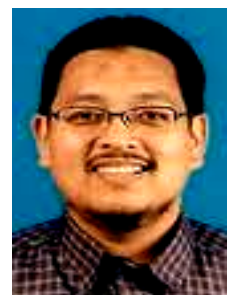

A. F. Sadullah is a member of Institution of Engineers Malaysia (IEM). Academically, he has a Ph.D. in Transport Studies from the University of London, United Kingdom. He has a master's of science in Transport from the same university and a bachelor in Civil Engineering from the Catholic University of America, Washington, United States. He also holds a Diploma of Imperial College (DIC) from the Imperial College of Science, Technology and Medicine. He is presently a professor in Transport Studies at the Schoo of Civil Engineering, Universiti Sains Malaysia (USM). He is widely regarded as a leading expert in transport matters in the country. He was the Director-General of the Malaysian Institute of Road Safety Research (MIROS) between 2008 and 2011, and was critical behind many road safety strategies of the country. Before MIROS, he was Dean of the School of Civil Engineering of USM. Earlier in his career at USM, he was the Programme
Chairman of Geotechnical, Highway and Transportation Engineering, Coordinator of the Engineering Innovation and Technology Development Unit (EITD), Research dean for the Engineering and Technology Platform and the pioneering Innovation director of USM. Professionally,

Prof. Dr. Ahmad Farhan Mohd Sadullah is a council member of the Road Engineering Association of Malaysia (REAM), member of the Institution of Transportation Engineers (ITE), Road Engineering Association of Asia and Australasia (REAAA), Transportation Science Society of Malaysia (TSSM), and ITS Malaysia. He is presently an International Scientific Committee (ISC) member of the East Asia Society of Transportation Science (EASTS) and is the Chair of the World Road Association (PIARC) Technical Committee C. 2 on Road Safety Operations. 